\title{
Modeling large-scale human alteration of land surface hydrology and climate
}

\author{
Yadu N. Pokhrel ${ }^{1 *}$, Farshid Felfelani ${ }^{1}$, Sanghoon Shin ${ }^{1}$, Tomohito J. Yamada ${ }^{2}$ and Yusuke Satoh ${ }^{3}$
}

\begin{abstract}
Rapidly expanding human activities have profoundly affected various biophysical and biogeochemical processes of the Earth system over a broad range of scales, and freshwater systems are now amongst the most extensively altered ecosystems. In this study, we examine the human-induced changes in land surface water and energy balances and the associated climate impacts using a coupled hydrological-climate model framework which also simulates the impacts of human activities on the water cycle. We present three sets of analyses using the results from two model versions - one with and the other without considering human activities; both versions are run in offline and coupled mode resulting in a series of four experiments in total. First, we examine climate and human-induced changes in regional water balance focusing on the widely debated issue of the desiccation of the Aral Sea in central Asia. Then, we discuss the changes in surface temperature as a result of changes in land surface energy balance due to irrigation over global and regional scales. Finally, we examine the global and regional climate impacts of increased atmospheric water vapor content due to irrigation. Results indicate that the direct anthropogenic alteration of river flow in the Aral Sea basin resulted in the loss of $\sim 510 \mathrm{~km}^{3}$ of water during the latter half of the twentieth century which explains about half of the total loss of water from the sea. Results of irrigation-induced changes in surface energy balance suggest a significant surface cooling of up to $3.3 \mathrm{~K}$ over $1^{\circ}$ grids in highly irrigated areas but a negligible change in land surface temperature when averaged over sufficiently large global regions. Results from the coupled model indicate a substantial change in $2 \mathrm{~m}$ air temperature and outgoing longwave radiation due to irrigation, highlighting the non-local (regional and global) implications of irrigation. These results provide important insights on the direct human alteration of land surface water and energy balances, highlighting the need to incorporate human activities such as irrigation into the framework of global climate models and Earth system models for better prediction of future changes under increasing human influence and continuing global climate change.
\end{abstract}

Keywords: Hydrology, Climate, Human impacts, Modeling

\section{Background}

Rapidly expanding human activities have profoundly affected various biophysical and biogeochemical processes of the Earth system over a broad range of scales, and freshwater systems are now amongst the most extensively altered ecosystems (Postel et al. 1996; Vitousek et al. 1997; Nilsson et al. 2005; Carpenter et al. 2011). Human management of land and water resources began with the advent of settled agriculture $\sim 10,000$ years ago

\footnotetext{
*Correspondence: ypokhrel@egr.msu.edu

1 Department of Civil and Environmental Engineering, Michigan State University, East Lansing, Ml 48824, USA

Full list of author information is available at the end of the article
}

(Marsh and Lowenthal 1965; Postel 1999), but the pervasive alteration of freshwater systems through flow regulation and large-scale water diversion began to accelerate rapidly during the twentieth century as a result of proliferation in dam construction and widespread agricultural expansion to fulfill the growing needs for water, food, and energy for the global population that quadrupled in the past 100 years. These large-scale water management practices have brought enormous benefits to our societies but also resulted in an unprecedented scale of negative environmental consequences (Vitousek et al. 1997; Postel et al. 1996; Nilsson et al. 2005; Micklin 2007; Rockström et al. 2009; Carpenter et al. 2011; Newbold et al. 2016). Today, it has become clear that mankind, through 
its actions, is conducting a planetary-scale experiment potentially pushing many Earth system processes to their tipping points (Newbold et al. 2016; Rockström et al. 2009).

Mounting evidences from ground- and satellite-based observations indicate that the human footprint on freshwater and ecological systems is now widespread across the planet and is widening at an alarming rate. These evidences have already shown that (1) most of the large river systems around the world have been heavily fragmented (Dynesius and Nilsson 1994; Vörösmarty et al. 1997; Gleick 2003; Nilsson et al. 2005); (2) more than 40\% of the global land surface has been modified by human-induced land cover change (Ramankutty et al. 2008; Pielke 2005; Foley et al. 2005); (3) groundwater storages in the world's largest aquifer systems are depleting at an alarming rate due to excessive pumping (Rodell et al. 2009; Wada et al. 2010; Pokhrel et al. 2012a, 2015; Scanlon et al. 2012; Konikow 2013; Long et al. 2013; Voss et al. 2013; Döll et al. 2014; Famiglietti 2014; Joodaki et al. 2014); and (4) some of the world's largest inland water bodies such as the Aral Sea are fast disappearing due to human alteration of water balance within their drainage areas (Micklin 1988, 2007; Lemoalle 2004; AghaKouchak et al. 2015). Today, as we enter into a new geological epoch termed as the "Anthropocene" (Crutzen 2002; Lewis and Maslin 2015), human forces have become so profound and pervasive that they rival other climatic factors in driving terrestrial water systems in many regions (Sanderson et al. 2002; Steffen et al. 2007; Rockström et al. 2009; Vörösmarty et al. 2010; Wagener et al. 2010; Carpenter et al. 2011). Because of such widespread human perturbations of natural systems, it is not meaningful anymore to study freshwater systems and their interactions with climate without considering human activities (Oki and Kanae 2006).

Decades of ground-based observations have enabled us to better understand the changes in the Earth's water cycle over varying spatial and temporal scales. In recent decades, satellite observations, such as those from the Gravity Recovery and Climate Experiment (GRACE) satellite mission (Tapley et al. 2004), have further enabled us to better monitor the changing surface and groundwater systems especially in relation to the changing climate and growing human interventions. However, the large observational data synthesis alone is not sufficient to attributing the observed changes to natural climatic and human factors and thereof to realistically predict future changes in the rapidly changing environment where stationarity is suggested to be non-existent (Milly et al. 2008). These issues call for the urgent need to develop new tools that can be used to accurately reproduce the past and realistically predict the future. Hydrological models are the predictive tools used to study the changes in different branches of the terrestrial water cycle. Some of these models, referred to as the land surface models (LSMs), are also used to represent land surface hydrology and simulate lower boundary conditions in general circulation models (GCMs) and Earth system models (ESMs). Both the hydrological models and LSMs have been used for a wide ranging studies of the water cycle over the past as well as for future projection of water resources availability (Arnell 1999; Oki and Kanae 2006; Döll 2009; Hanasaki et al. 2013; Wada et al. 2013; Haddeland et al. 2014; Schewe et al. 2014; Gosling and Arnell 2016; Pokhrel et al. 2014). Over the past several decades, these models have been advanced through intensive improvements of schemes representing vegetation, soil moisture, and groundwater processes (Sellers et al. 1997; Lawrence et al. 2011), but most of these sophistications are focused on simulating the natural water cycle, and relatively little progress has been made in modeling human impacts. In particular, while noteworthy progress has been made in representing human factors in global hydrological models (GHMs) (Haddeland et al. 2011) designed for offline water resource assessment, most current-generation LSMs still lack the representation of human factors, meaning that most GCMs and ESMs currently lack the representation of human factors. Recent years have seen increased attention both from hydrologic and climate modeling communities in incorporating human activities into LSMs and GCMs but some challenges and opportunities still remain (Pokhrel et al. 2016; Nazemi and Wheater 2015a, b).

In this study, we contribute to the discussion on how human land-water management activities (i.e., irrigation, flow regulation, and groundwater pumping) are affecting freshwater systems and climate over large scales. We subsequently highlight the importance of representing these human activities in global GCMs and ESMs to better simulate the coupled natural-human systems in the face of growing human influence on freshwater systems and ongoing climate change. The primary goal of the paper is to examine the large-scale alterations of land surface water and energy balances due to human activities and to investigate the resulting climate impacts and feedback. We present our analysis at both global and regional scales because while the human-induced changes in surface water balance affect the water cycle primarily at local to regional scales, the resulting changes in surface energy balance can affect the climate system over a varying range of spatial scales. For the water balance analysis, we present a regional case study of the Aral Sea in central Asia. A number of observation-based studies (e.g., Micklin 1988, 2007; Small et al. 2001) have reported that the large alteration of river flows in the Aral Sea basin was the primary reason for the rapid desiccation of the sea 
during the last several decades. However, to the authors' knowledge, hydrological model simulations have been rarely used to mechanistically examine the natural and anthropogenic causes of changes in inflows to the sea. As such, the attribution of the observed changes in Aral Sea inflow to natural and anthropogenic factors remains relatively unexplored. For the analysis of surface energy balance, we present both regional and global results because the irrigation-induced changes in surface energy balance have been suggested to affect the climate system at local, regional, as well as global scales (Sacks et al. 2009).

We use the results from a coupled hydrological-climate model framework developed by linking a global LSM - that accounts for human land-water management activities - with its parent GCM to examine the extent of direct human influence on freshwater systems and climate over large scales. To attribute the observed changes in water and energy balances to human and climate factors, we first use two offline LSM experiments: one with and the other without human activities. Then, the climate impacts are examined by using the coupled model (i.e., by coupling the LSM with its parent GCM). Again, we conduct two experiments: one with and the other without human activities, resulting in a total of four experiments (i.e., two offline and two online). Specifically, we investigate (1) how the increased use of water for irrigation in the Aral Sea basin contributed to the anthropogenic desiccation of the sea during the latter half of the twentieth century, which is sometimes referred to as "one of the very greatest ecological problems" of the twentieth century (Micklin 1988); (2) the impacts of irrigation on land surface energy balance over regional scales; and (3) the global and regional climate impacts of irrigation-induced increase in atmospheric water vapor content. In the rest of this paper, we first describe the model in "Model, data, and experimental settings," present research findings in "Results and discussion," and provide concluding remarks in "Summary and conclusions."

\section{Model, data, and experimental settings}

The model used in the study is HiGW-MAT (Pokhrel et al. 2015), which was developed by incorporating human impact $(\mathrm{Hi})$ modules (e.g., reservoir operation, crop growth, irrigation, and water withdrawal for domestic, industrial, and agricultural purposes) and groundwater $(\mathrm{GW})$ dynamics and pumping schemes into a global LSM called the minimal advanced treatments of surface interaction and runoff (MATSIRO) (Takata et al. 2003). MATSIRO is an LSM developed to compute biophysical exchanges in the atmospheric GCM (AGCM) called MIROC (the Model for Interdisciplinary Research on Climate) (Hasumi and Emori 2004). MATSIRO estimates the exchange of energy, water vapor, and momentum between the land surface and the atmosphere on a physical basis by taking into account the effects of vegetation on surface energy balance using a multilayer canopy model (Watanabe 1994) and a photosynthesis-stomatal conductance model (Collatz et al. 1991). The vertical movement of soil moisture is estimated by numerically solving the Richards equation (Richards 1931), and the land surface hydrological processes are represented by employing a simplified version of the TOPMODEL (Beven and Kirkby 1979; Stieglitz et al. 1997).

Since river routing and human land-water management activities were not considered in the original MATSIRO, we incorporated a global river routing scheme (Oki and Sud 1998) and various schemes representing human land-water management practices (e.g., reservoir operation, crop growth, irrigation, water withdrawal, and environmental flow requirements) into the model in our previous studies (Pokhrel et al. 2012a, b). Further, the soil model of MATSIRO was improved by representing a prognostic water table dynamics scheme (Yeh and Eltahir 2005) to explicitly simulate the vertical flux exchange between saturated and unsaturated soil zones (Koirala et al. 2014). In our recent study (Pokhrel et al. 2015), we further enhanced the model by representing groundwater pumping scheme to explicitly simulate groundwater withdrawal and recharge, enabling us to estimate groundwater withdrawal and depletion within the model and without using any auxiliary information. The latest version of the model (i.e., HiGW-MAT) thus simulates the flow and storage of water globally, taking into account human water use for various purposes and its influence on surface water and energy balance over global and continental scales.

In this study, we use HiGW-MAT for both offline (forced by observation-based meteorological data) and online (coupled with MIROC AGCM version 3.2) simulations. We carry out two sets of simulations-one by turning the human impact schemes off and the other by turning them on-in both offline and online modes, resulting in a set of four simulations in total. We refer to the former setting as natural setting (hereafter NATOffline and NAT-Online experiments) and the latter as human impact setting (hereafter HI-Offline and HIOnline experiments). Forcing data for offline simulations are taken from two different sources considering their temporal coverage for different analyses. For the historical (1951-2000) simulations used to examine the Aral Sea inflow, we use the NCC forcing data (Ngo-Duc et al. 2005), and for the simulations used to examine irrigation-induced alteration of surface energy balance for the period 1998-2010, we used the data from Kim et al. (2009) because this period is not covered by NCC data. We use these two particular forcing datasets because 
they have been used in our previous studies that validated various model components used here (Pokhrel et al. 2012a, b, 2015). The uncertainties arising from the use of different forcing datasets, especially precipitation, have also been discussed in our previous studies (Pokhrel et al. 2012a, b). All other model parameters and data for human activity modules are identical to those used by Pokhrel et al. (2015). Grid-based and time-varying (annual) irrigated areas for the entire simulation period are derived by using the Global Map of Irrigated Areas (GMIA) (Siebert et al. 2015) and the methodology described in Pokhrel et al. (2012b).

For online simulations, we couple HiGW-MAT with MIROC AGCM version 3.2 (Hasumi and Emori 2004) and dynamically simulate the land-atmosphere interactions including the land disturbance due to human activities such as irrigation and groundwater use. The online simulations are initialized with the soil moisture states from the offline simulations. Online simulations are conducted for the period 1998-2010, and all model parameters related to land surface hydrology and human activities are identical to those used in offline simulations. While the offline simulations are performed at the spatial resolution of $1^{\circ} \times 1^{\circ}$, the online experiments are conducted at $\mathrm{T} 42$ resolution $\left(\sim 2.81^{\circ}\right)$ with 20 vertical sigma levels. The spatial resolutions used for both the offline and online simulations are typical for global models and are fairly adequate to capture the large-scale spatial patterns and long-term trends discussed in the present study. The LSM is run at an hourly interval, and the output is saved on a daily basis.

The offline model results from both the original MATSIRO and the integrated HiGW-MAT models have been extensively validated using ground- and satellite-based observations of various hydrologic fluxes and stores in our previous studies (Koirala et al. 2014; Pokhrel et al. 2012a, b, 2015). In particular, river discharge and terrestrial water storage (TWS) variations, irrigation water use, and groundwater withdrawals and depletion have been evaluated over varying spatial domains and temporal scales. In this study, we briefly revisit the evaluation over the Aral Sea basin. We use the observed river discharge from the Global Runoff Data Center (GRDC) for the evaluation of river discharge, and the TWS data derived from the GRACE satellite mission (Tapley et al. 2004) are used to evaluate the simulated TWS variations over the Aral Sea basin.

\section{Results and discussion}

We present three sets of results. First, we analyze the human-induced changes in water balance for the Aral Sea region. We focus on this region because, to the authors' knowledge, very few studies have used model results to mechanistically explain the natural and human-induced changes in river flows that caused the desiccation of the sea over the past several decades. Second, we present the results from offline simulations at both regional and global scales to examine the changes in surface energy balance due to irrigation. Finally, we use online model simulations to detect the irrigation-induced climate impacts, again at both regional and global scales.

\section{Human alteration of water balance: the case of Aral Sea}

We evaluate the simulated streamflow in the river basins draining to the Aral Sea and the changes in TWS over the entire Aral Sea basin with the observations from GRDC and GRACE satellite mission, respectively. The Aral Sea is a large terminal saline lake located among the deserts of Central Asia. It drains a total area of $\sim 1.8$ million $\mathrm{km}^{2}$ spread across seven nations: Uzbekistan, Turkmenistan, Kazakhstan, Afghanistan, Tajikistan, Pakistan, and Iran (Micklin 2007). The main source of water to the sea is the discharge of the Syr Darya and Amu Darya river basins, and the sea has no surface outflow. After mid-twentieth century, agricultural diversions of river water increased substantially throughout the Aral Sea drainage area, resulting in a net loss of water from the sea owing to increased evapotranspiration and groundwater recharge (Micklin 1988; Small et al. 2001). As a result of reduced inflow, the net water balance of the sea became negative after 1960 (Small et al. 2001); it has been suggested that the lake water level has fallen by $23 \mathrm{~m}$, resulting in surface area shrinkage by $\sim 74 \%$ and reduction in volume by $\sim 90 \%$ during the latter half of the twentieth century (Micklin 2007).

Figure 1 shows the comparison of simulated (HIOffline) and observed total annual discharge from the Amu Darya and Syr Darya river basins, which are the major contributors of surface inflow to the Aral Sea. It is evident from the figure that the model captures the long-term trend of annual discharge fairly well with good

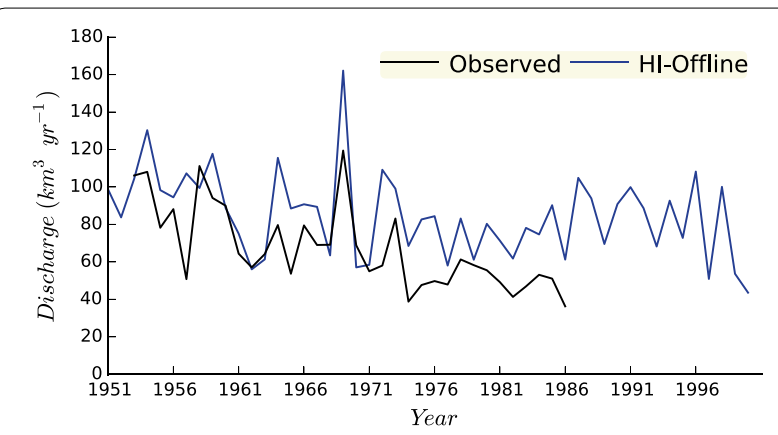

Fig. 1 Comparison of the combined annual river discharge from Amu Darya and Syr Darya rivers at Kerki and Tyumen Aryk stations, respectively, from the model (blue) and observations (black). Observed data are shown only for the period available 
agreement for most years with certain overestimations during the late 1970s and early 1980s; results for the subsequent years could not be evaluated owing to the lack of observations in GRDC database. The relatively smaller declining trend in the simulated flows compared to the trend in observations can be attributed primarily to two factors: the uncertainties in forcing data, especially precipitation, and uncertainties in human impact simulations, especially those arising from the uncertainties in irrigation practices and irrigated areas. Water withdrawals and irrigation have been found to significantly alter the river flow and trigger off a considerable decrease (more than \%10 in some regions) in long-term average annual river discharge (Döll et al. 2009). Further, the irrigation system in the Aral Sea basin is dominated by furrows with relatively lower efficiency compared to modern practices (Micklin 2014). Therefore, the lack of detailed irrigation parameterization in the irrigation schemes used in global LSMs such as HiGW-MAT can cause such discrepancies between the observed and simulated river flows. Despite certain differences between model simulations and observations, we consider the use of simulated flows to be acceptable to assess irrigation-induced changes in surface water balance because any biases in the long-term trend will have similar magnitudes and hence the difference between two simulations (with and without human impacts) will not be significantly affected. It should also be noted that the results presented in Fig. 1 do not represent the exact volume of Aral Sea inflow because the gaging stations in both rivers are located substantially in the upstream of the Aral Sea shore; the flow in the downstream may increase due to addition of local runoff or may decrease due to evaporation from wetlands, infiltration into groundwater, and/or added human water use along its course to the sea (Small et al. 2001). Indeed, the long-term combined mean annual flow at the gaging stations in the two rivers both from observations $\left(67 \mathrm{~km}^{3} /\right.$ year $)$ and model $\left(83 \mathrm{~km}^{3} /\right.$ year $)$ differ significantly from the Aral Sea inflow reported by various previous studies (e.g., Raskin et al. 1992; Small et al. 1999; Micklin 2007, 2010).

To add further confidence to our model simulations, we compare the variations of TWS from the HI-Offline experiment with the TWS variations derived from the GRACE satellite mission. Figure 2 presents the comparison of the seasonal cycle of simulated TWS anomaly averaged over the combined area of the Amu Darya and Syr Darya river basins with GRACE data (Level-3, Release-5). Results indicate that the model well captures the seasonal dynamics of the GRACE-detected TWS variations over the 2003-2010 period. In Fig. 2, the individual TWS components from model simulations, namely river water, soil moisture, and groundwater, are

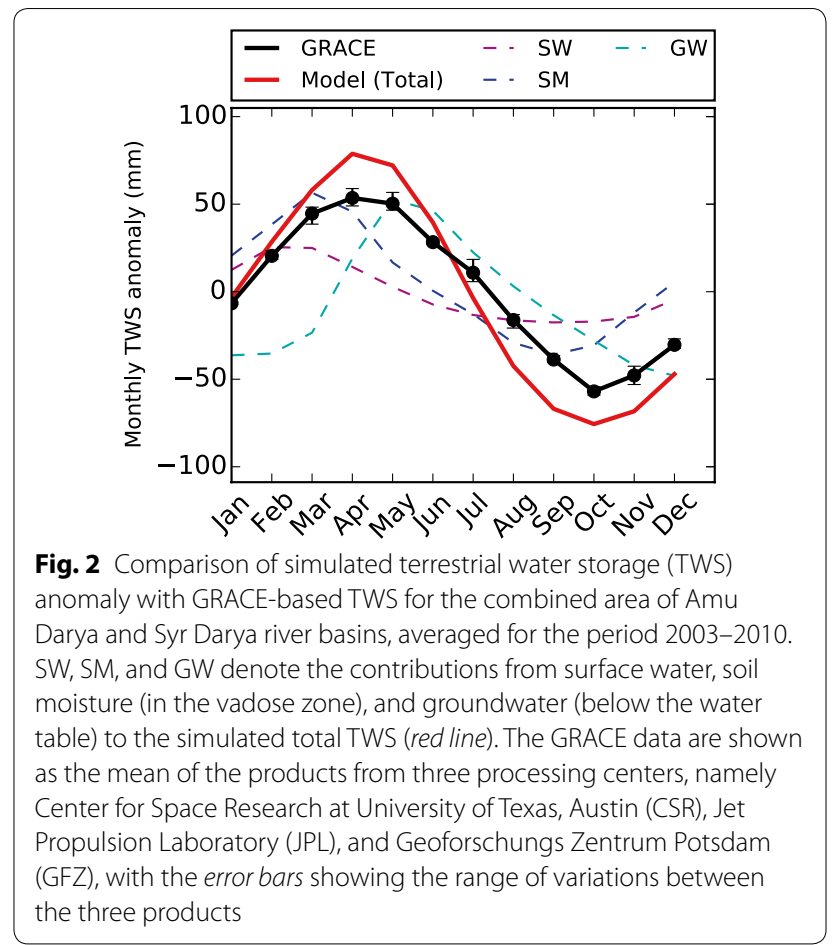

also shown. It is evident that the model tends to overestimate TWS amplitude compared with GRACE but it is also clear that the seasonal dynamics of TWS variations is simulated well by the model, which adds confidence to the results of our offline simulations.

Next, we examine the changes in long-term inflow to the Aral Sea due to human-induced alteration of water balance in the two river basins. An early study by Micklin (1988) suggested that, under natural conditions, $\sim 111 \mathrm{~km}^{3} /$ year of surface water would be generated over the Aral Sea basin of which about half reaches the sea because of losses such as through evapotranspiration and infiltration within the drainage area. The study also suggested that $\sim 40 \mathrm{~km}^{3} /$ year of flow reached the sea during 1960s. Other studies have reported a larger inflow. For example, Raskin et al. (1992) suggested that the average surface runoff from the Aral Sea basin is $\sim 120 \mathrm{~km}^{3}$ / year under natural conditions. Small et al. (1999) compared the model results of $162 \mathrm{~km}^{3} /$ year with the observed inflow of $\sim 110 \mathrm{~km}^{3} /$ year for $1988-1993$ period. Similarly, Shibuo et al. (2007) compared their simulated inflow of 77 and $16 \mathrm{~km}^{3} /$ year for 1901-1950 and 19832002 periods, respectively, with the reported values of 71 and $12 \mathrm{~km}^{3} /$ year. More detailed studies based on water balance using observational synthesis over decades suggest a range of decadal inflows from 55 to $4 \mathrm{~km}^{3} /$ year for different periods from 1910 to 2010 (Micklin 2007, 2010).

Despite the varying estimates of the inflow to the sea, the net change in sea volume over the past several 
decades is relatively accurately known; it has been estimated that the sea amounted to $\sim 1089 \mathrm{~km}^{3}$ during the 1960s but reduced to $\sim 108$ and $\sim 84 \mathrm{~km}^{3}$ in 2006 and 2009 , respectively, resulting in the net loss of $\sim 1000 \mathrm{~km}^{3}$ over about four decades (Micklin 2007, 2010). The observed desiccation of the sea is believed to be a consequence of a combination of climatic and anthropogenic changes including the reduction in inflow from rivers, changes in regional climate and lake water balance (i.e., precipitation-evaporation), and alteration of groundwater flows to and from the sea. But it has been suggested that the primary cause is the reduction in river discharge to the sea due to increased human water consumption in the Aral Sea basin to support expanding agricultural activities, especially to increase the production of rice and cotton (Micklin 2007). Various aforementioned studies have often used the observed inflow over long terms to portray a picture of the desiccation of the sea, and some model-based studies have also studied the changes in regional climate and lake water balance over certain period of time (Small et al. 1999, 2001; Shibuo et al. 2007); however, what remains unaddressed is the attribution of the reported changes in inflow to natural and anthropogenic causes which can be done only through a comparative analysis of model results with and without considering human factors. Here, we directly address this issue by using the 50-year model experiment carried out by turning human factors on and off.

Figure 3a depicts the anomaly of combined inflow from Amu Darya and Syr Darya rivers into the Aral Sea (at the inlet to the sea) from offline simulations with (HI-Offline) and without (NAT-Offline) human activities. It is obvious from the figure that, even under natural conditions, the inflow to the sea was substantially lower than the longterm mean during late 1950s, early 1960s, 1970s, and late 1990s. These results imply that the changes in inflow

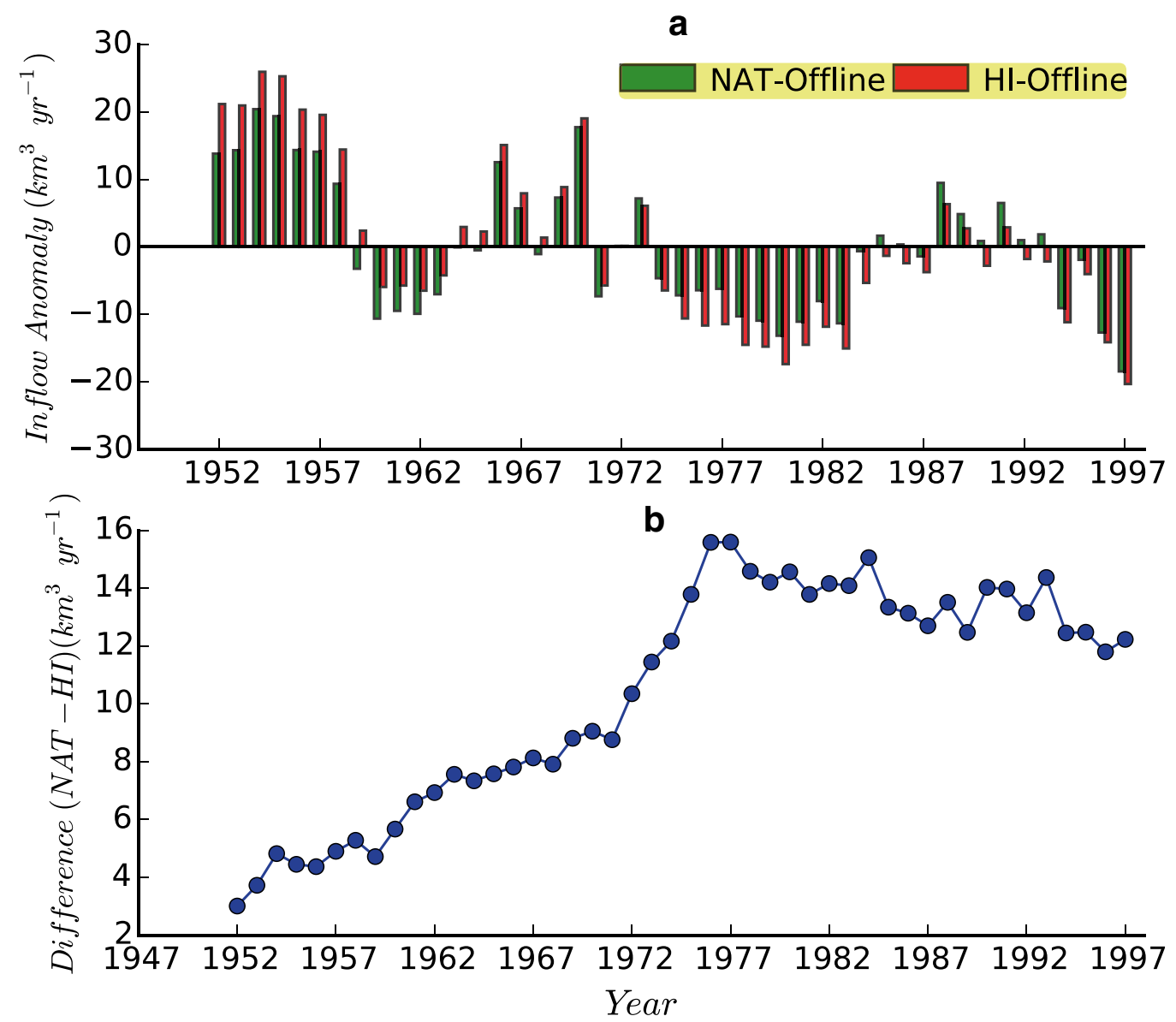

Fig. 3 Anomaly of the inflow to the Aral Sea from two major river basins simulated by NAT-Offline and HI-Offline experiments (a), and the difference (NAT-Offline-HI-Offline) in annual flow volume between the results of two simulations (b). Results are shown as five year running mean. Note that the NAT-Offline and HI-Offline results in (a) have different climatological mean and that the results in (b) are the difference of the absolute flow values 
were not entirely due to human water use, even though the meteorological forcing data used in both offline simulations could already include some effects of the anthropogenic alteration of regional water balance. It is evident that the inflow under both simulations was high during 1952-1957, decreased substantially during 1960-1962, attained its highest value in 1969 as a results of higher precipitation and lower temperatures as also suggested by Shibuo et al. (2007), and remained consistently low from 1973 onwards.

Figure $3 \mathrm{~b}$ displays the difference between inflows from the two model runs. It is obvious that the human water use resulted in substantial inflow reduction with an increasing trend from 1950s to mid-1970s; the largest difference of $\sim 15 \mathrm{~km}^{3} /$ year can be observed during the mid1970s. The temporal patterns in the difference shown in Fig. $3 \mathrm{~b}$ reflect the changes in irrigation water demands over time, caused primarily by two factors: changes in irrigated areas and climate conditions. During the 1950s, low irrigated areas and wet climate conditions resulted in a relatively small difference between the two simulations. The difference increased substantially until the 1970 s, caused by the monotonous rise in irrigated areas during this period and the relatively dry climate conditions in some years (negative flow anomalies in Fig. 3a). The difference peaked around mid-1970s and remained relatively stable with certain inter-annual fluctuations, mostly driven by climate variability. It is important to note that wetter soil conditions in some years can be carried over to the subsequent years resulting in less irrigative demands. The cumulative difference over the 50-year period is $\sim 510 \mathrm{~km}^{3}$, which suggests that, based on the model simulations, almost half of the change in sea volume can be attributed to direct anthropogenic alteration of river flow. Certainly, as discussed earlier, climate change and variability, which could be both natural and human-induced, also contributed largely to the reduction in inflow to the Aral Sea. Changes in lake evaporation and groundwater inflow/outflow may also have partially contributed to the overall water balance which are not considered in our study. Moreover, our results are from an offline model which does not take into account the interactions and feedback among land and atmospheric drivers of water cycle change. A more comprehensive analysis using a coupled land-lake-atmosphere model that also considers human land-water management is needed to fully attribute the observed changes to various climatic and anthropogenic factors.

\section{Irrigation-induced changes in surface energy balance}

The anthropogenic alterations of river flows discussed in the previous section have important implications on land surface energy balance. In particular, water used for irrigation creates wetter soil conditions, fundamentally enhancing evapotranspiration which in turn transforms the surface energy balance causing surface cooling (Kueppers et al. 2007). In offline simulations, these alterations are manifested as changes in latent and sensible heat fluxes accompanied by reduced land surface or skin temperature. Such impacts are not highly pronounced over the entire Aral Sea basin (Fig. 4) because in most of the region only a relatively small fraction of the model grid cells is irrigated (Fig. 5). Therefore, we focus the discussion here on other global regions that are extensively irrigated, and can have potential impacts on global climate system.

Figure 4 displays the grid-averaged changes in annual mean land surface skin temperature in response to increased latent heat flux due to irrigation. Decrease in mean annual surface temperature averaged over all irrigated grid cells is rather small $(\sim 0.04 \mathrm{~K}$ or $\sim 1.2 \%)$, but the changes are particularly pronounced in the highly irrigated areas [Fig. 5; data source: Siebert et al. (2015)] and during the growing seasons. Surface cooling is not highly pronounced in the modestly irrigated areas in South America, Australia, Europe, and the southern part of Africa, where irrigation causes only a small change in surface energy balance. In Southeast Asia and the eastern part of China, where the model simulates large amounts of irrigation water use (Pokhrel et al. 2012a), surface energy balance is not affected by irrigation, because these regions are characterized by humid climate and energylimited regime where increase in soil water content does not necessarily increase evapotranspiration due to energy limitation. In addition, the major crop grown in many of these regions is rice and irrigation is applied to maintain soil moisture at near full saturation during the growing season, which often results in immediate increase in surface runoff during heavy rainfall over flooded rice paddies. As such, only a small percentage of irrigation water is actually consumed by crops and the rest is discharged back to rivers as return flow.

In highly irrigated grid cells in parts of northwest India and western US, surface cooling of up to $3.3 \mathrm{~K}$ is found during growing season (Fig. $4 \mathrm{~b}, \mathrm{c}$ ). The actual change in surface temperature over the irrigated regions could be even larger because the results shown are the grid-average values. Such large surface cooling simulated by the model is accompanied by significant increase in latent heat flux of up to $50 \mathrm{~W} / \mathrm{m}^{2}$ during the growing season as reported in our previous study (Pokhrel et al. 2012a). These results, which are in line with previous studies (e.g., Haddeland et al. 2006), suggest that the irrigationinduced changes in land surface energy balance when averaged over large domains (e.g., large global basins) could be very small but are highly pronounced within 


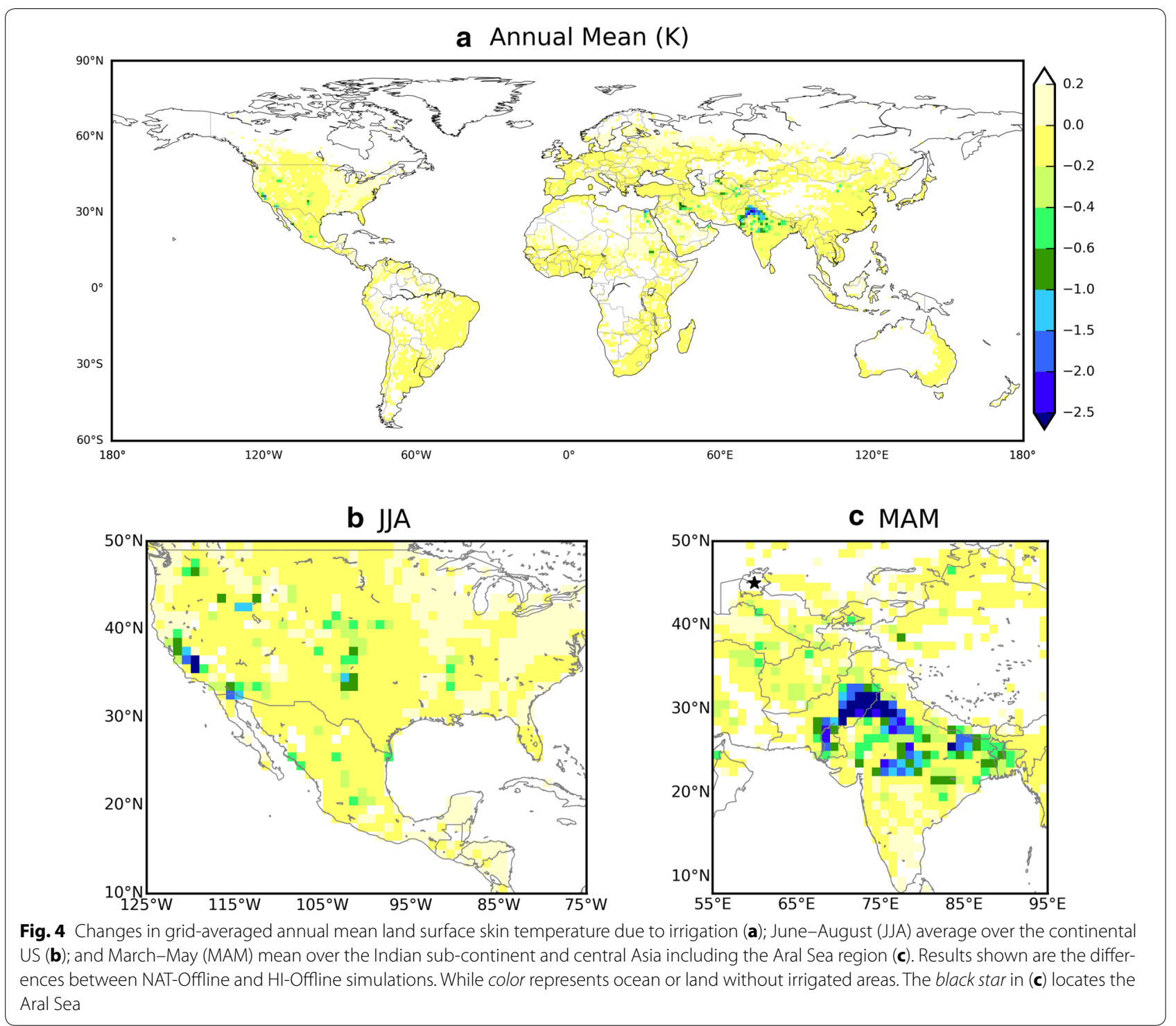

and around the highly irrigated regions. Such alteration of surface energy balance due to irrigation can potentially alter the climate system at varying scales by making the lower atmosphere cooler and supplying additional moisture into the atmosphere, which we discuss in the next section.

\section{Climate impacts of irrigation}

Finally, we examine the impacts of irrigation on regional and global climate using the results from two online simulations: one with and the other without human activities. A number of studies have examined the impacts of irrigation-induced changes in surface energy balance on regional and global climate (e.g., Boucher et al. 2004; Kueppers et al. 2007; Sacks et al. 2009; Puma and Cook 2010; Sorooshian et al. 2011; Lo and Famiglietti 2013).
These studies have consistently shown that irrigation can exert significant regional as well as global climate impacts; however, there are large disagreements in the quantification of the magnitude of these impacts among different models (Sorooshian et al. 2012). The disagreements among models can partly be attributed to the use of different irrigation schemes, most of which are rather simplistic and suffer from large uncertainties in estimating the irrigation amount itself (Pokhrel et al. 2016). Here, we expand on these existing studies by presenting new results from a coupled climate model that dynamically simulates the irrigation impacts on climate system by explicitly simulating irrigation demands within the model, also taking into account crop growth dynamics as well as the source of irrigation water (Pokhrel et al. 2012a, 2015). Thus, the model fully accounts for both the natural 


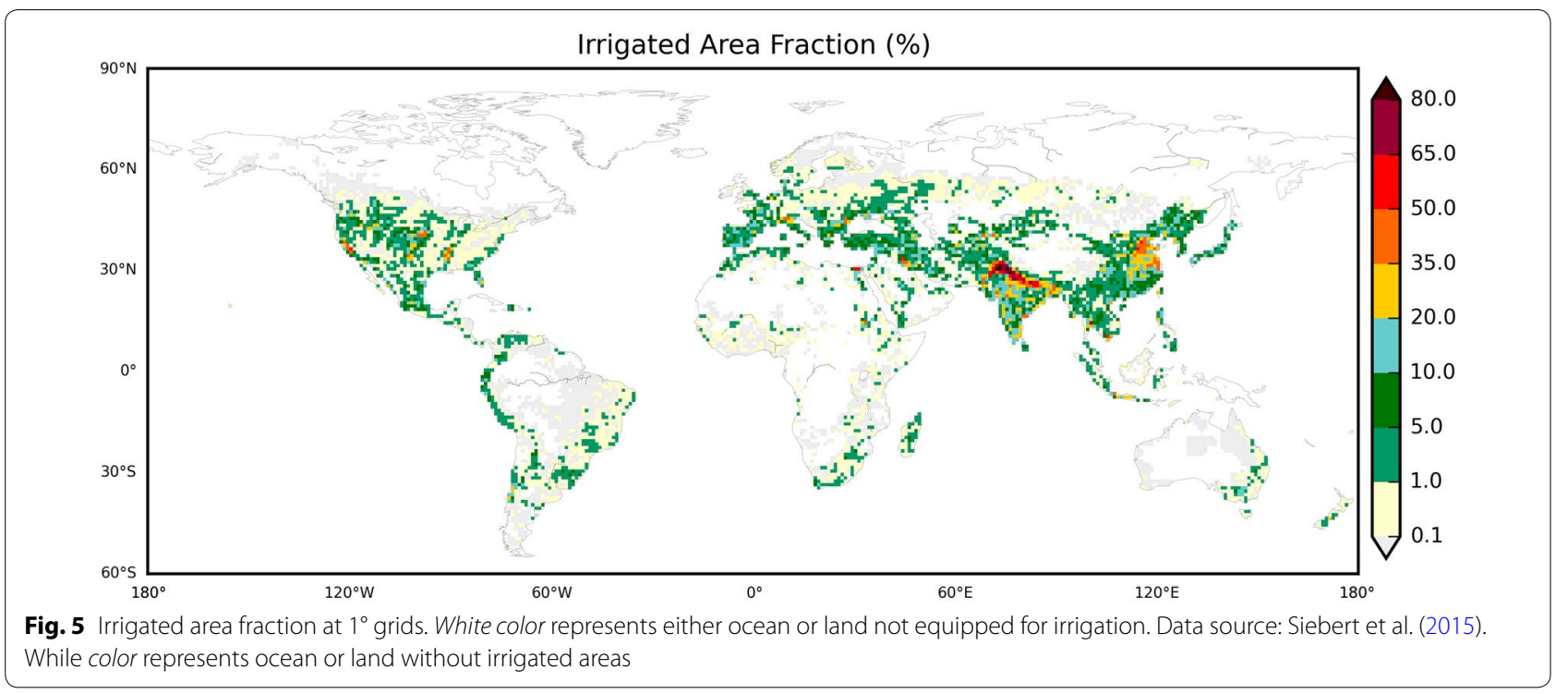

and human-induced terrestrial water balance within the climate model framework, making it one of the first of its kind.

Figure 6 shows the difference in $2 \mathrm{~m}$ air temperature from the NAT-Online and HI-Online experiments, averaged over the period 1998-2010 and for June-August (JJA) during which the temperature changes were found most profound among all seasons. The figure provides the following insights. First, it is evident that the coupled model simulates a decrease in $2 \mathrm{~m}$ air temperature over the highly irrigated regions (shown in Fig. 5) such as the northwestern India and parts of Pakistan as well as the central US, which coincide with the regions of large irrigation-induced surface cooling in our offline simulations (Fig. 4). Large negative temperature differences of up to $-3 \mathrm{~K}$ can also be seen in eastern China, and parts of Europe which also include irrigated areas. The dotted areas in Fig. 6 represent the grid cells that satisfy 95\% statistical significance in Student's $t$ test. Overall, these results are generally consistent with the findings of Sacks et al. (2009).

Second, substantial cooling can be observed even in areas with little or no irrigation, including the northern and northeastern Africa and northern Canada. And third, warming can be observed in regions including the mid-to-eastern areas in northern Eurasia, southern

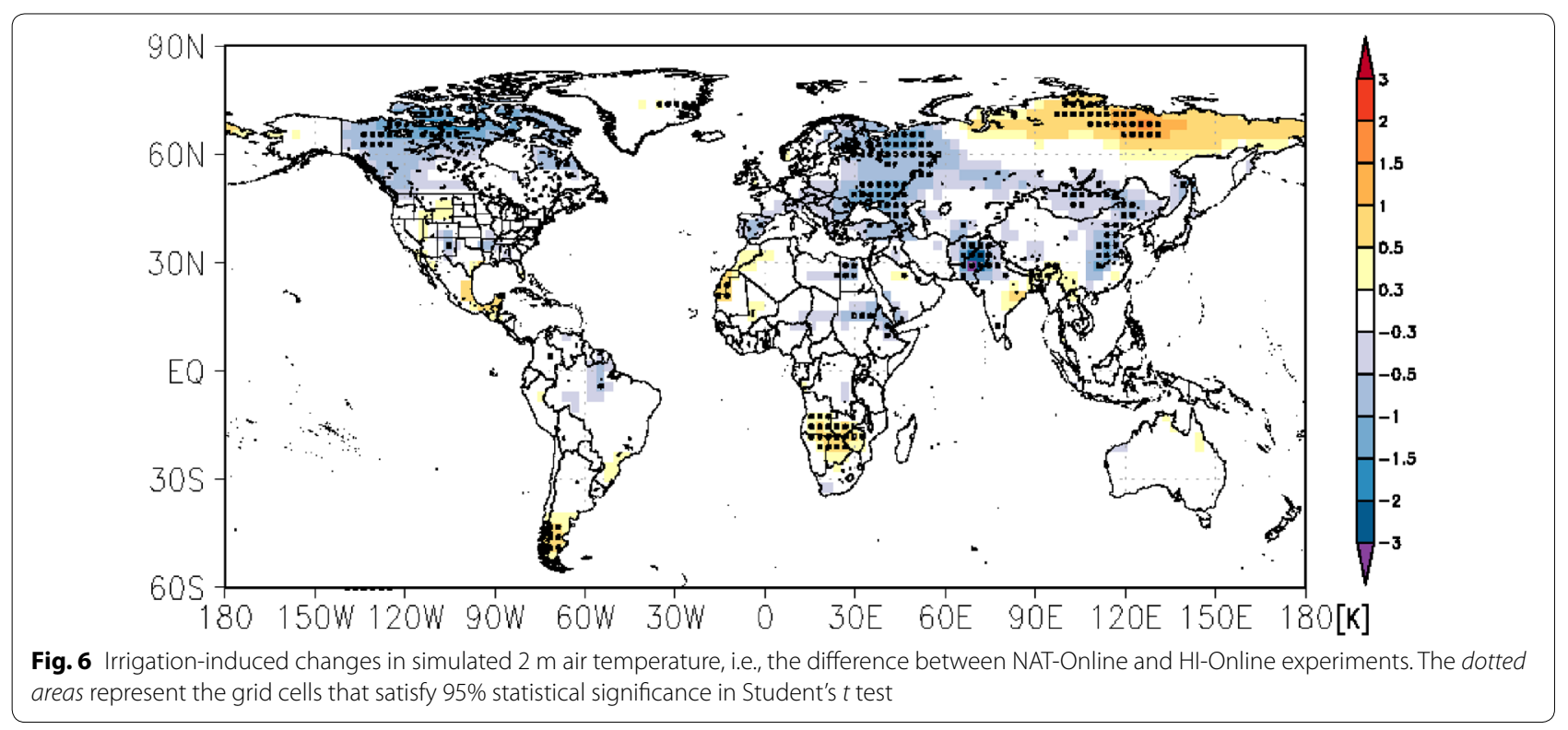


Africa, and central America. These results of varying degree of cooling and warming in regions within and beyond the irrigated regions suggest that the climate impacts of irrigation can be driven by non-local processes. The relatively weak signal (Fig. 6) in some of the highly irrigated grid cells around southern California (Figs. 4, 5) also suggests that the irrigation-induced cooling in the grid cell size of atmospheric models is highly non-local and is not always correlated directly with the surface cooling in offline simulations. Further, as suggested by Sacks et al. (2009), irrigation-induced evaporative cooling in one region should be offset by warming from the release of latent heat in other parts of the atmosphere, which implies that indirect effects such as changing cloud cover, and the accompanying changes in solar radiation, could be more important over larger scales and beyond irrigated areas. To assess such indirect effects, here we finally examine the changes in outgoing longwave radiation (OLR). The decrease in OLR is a result of lower surface temperatures and increased cloud content as a consequence of increased water vapor content in the atmosphere. Thus, the increased cloud cover adds a positive feedback on the reduction in OLR due to surface cooling by irrigation. As seen in Fig. 7, in the highly irrigated regions including the northwestern India, Pakistan, eastern China, and central US, thicker or frequent clouds and cooler $2 \mathrm{~m}$ air temperature (Fig. 6) due to increased water vapor from irrigated areas result in significant reduction in OLR. Similar to the changes in $2 \mathrm{~m}$ air temperature, regions away from irrigated areas such as the mid-to-eastern area on northern Eurasia experience increase in OLR as a result of increase in $2 \mathrm{~m}$ air temperature and reduction in cloud cover.

\section{Summary and conclusions}

In this study, we contribute to the discussion on how human land-water management activities (e.g., irrigation, flow regulation, and groundwater pumping) are affecting the freshwater system and climate over large scales. We subsequently highlight the importance of representing these human activities in global climate models and Earth system models to better simulate the coupled natural-human systems in the face of growing human influence on freshwater system and ongoing climate change. Results from a coupled hydrological-climate model framework developed by linking a global LSM-that accounts for human land-water management activitieswith its parent GCM are used to examine the changes in surface water and energy balances and their impacts on regional and global climate. First, the results from the offline model are used to examine the climate and humaninduced changes in the hydrology of the Aral Sea basin in central Asia and the associated impacts on the reduction in the volume of the sea over the latter half of the twentieth century. Simulated results of river discharge and terrestrial water storage (TWS) variations are evaluated with the observations from the GRDC and the GRACE satellite mission, respectively. Simulated river discharge for the Amu Darya and Syr Darya river basins, which are the major contributors to the Aral Sea inflow, are then used to examine the climate and human-induced changes in inflow to the sea over long terms. Results indicate that the direct anthropogenic alteration of river flow in the Aral Sea basin resulted in the loss of $\sim 510 \mathrm{~km}^{3}$ of water during the latter half of the twentieth century which explains about half of the recorded loss of water from the sea. Results also suggest that the inflow to the sea decreased

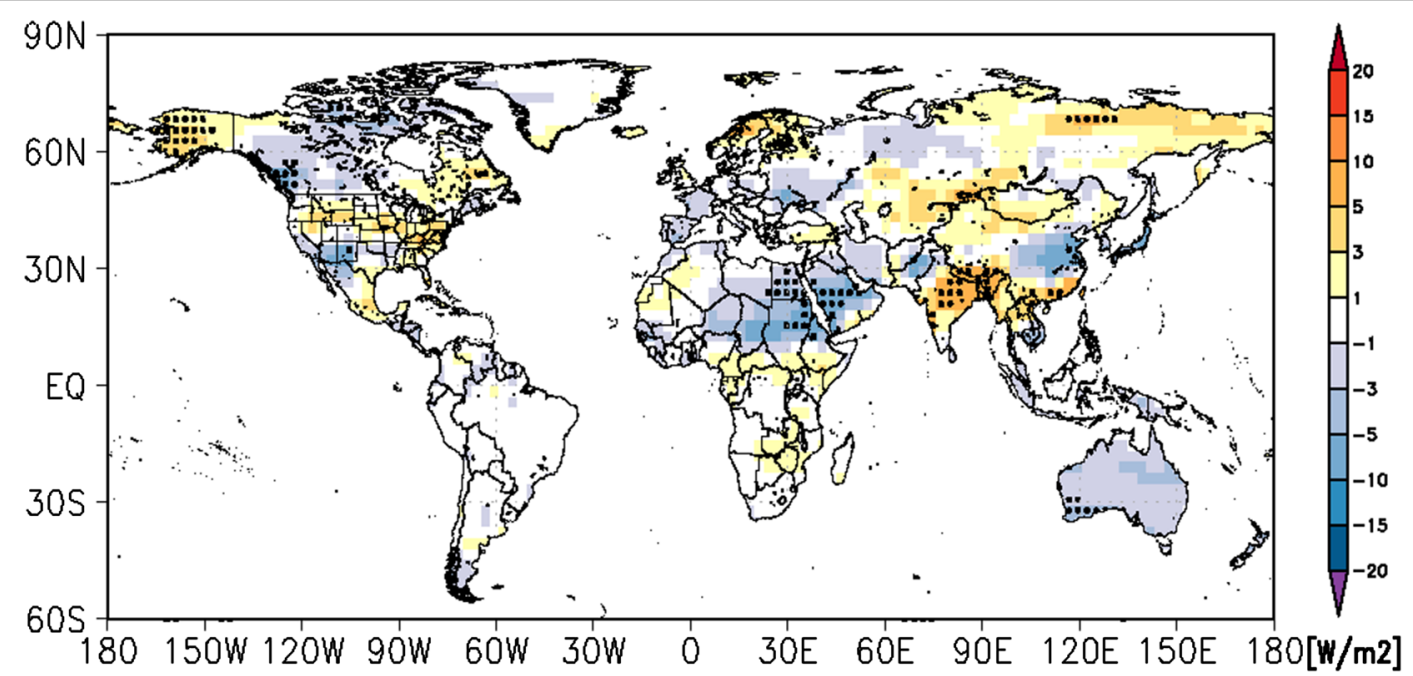

Fig. 7 Same as in Fig. 6 but for OLR outgoing longwave radiation 
over the analysis period even in the simulation without human activities, implying that the observed changes in the sea could partly be due to natural climate variability and trend. It is also found that the human-induced reduction in inflow to the sea changed over time, reflecting the changes in irrigation water demands caused by expanding irrigated areas and changing climate conditions (both inter-annual as well as inter-decadal variabilities).

Second, we use the results from two offline simulations (with and without human impacts) to discuss the changes in surface temperature as a result of changes in land surface energy balance due to irrigation over global and regional scales. Results of irrigation-induced changes in surface energy balance suggest a significant surface cooling of up to $3.3 \mathrm{~K}$ over $1^{\circ}$ grids in highly irrigated areas but a negligible change in surface temperature when averaged over sufficiently large global regions. Finally, we use the results from coupled land surface-climate model to examine the impacts of irrigation on climate over large scales. It is found that irrigation-induced evaporative cooling of the surface and associated increase in water vapor in the atmosphere substantially reduced $2 \mathrm{~m}$ air temperature in the vicinity of the highly irrigated areas. Results also suggest that the irrigation impacts are nonlocal causing substantial warming in regions far from irrigated regions. Further, we use the results of changes in outgoing longwave radiation (OLR) to examine the impacts of changing cloud cover resulting from irrigated areas. Changes in OLR are consistent with the changes in $2 \mathrm{~m}$ air temperature, suggesting substantial decrease in OLR within irrigated regions and substantial increase in regions beyond irrigated areas.

There are a number of factors that could have introduced certain errors in our results. For example, the simulated irrigation water use and the resulting alteration of river flows are directly impacted by forcing data, especially precipitation and temperature, which could contain significant uncertainties in some regions. Moreover, the errors in the spatial extent as well as the temporal evolution of irrigated areas and the simplifications in modeling irrigation practices also add further uncertainties in the simulated irrigation water use. In addition, the simulation of irrigation water demands in our online experiments could have been affected by the potential biases in the climatology simulated by the AGCM. Addressing these issues will be important directions for future research. Despite some limitations, this study provides important insights on the direct human alteration of land surface water and energy balances over large regions. Our findings also call for the need to incorporate human land-water management activities in LSMs and integrate such LSMs into the framework of Earth system models for more accurate attribution of the observed changes to natural and human-induced causes and realistic prediction of future changes under increasing human influence and continuing global climate change.

\section{Authors' contributions}

YNP designed the research; YNP and TJY conducted numerical simulations; all authors analyzed and discussed the results, and wrote the manuscript. All authors read and approved the final manuscript.

\section{Author details}

${ }^{1}$ Department of Civil and Environmental Engineering, Michigan State University, East Lansing, MI 48824, USA. ${ }^{2}$ Faculty of Engineering, Hokkaido University, N13 W8, Kita-ku, Sapporo, Hokkaido 060-8628, Japan. ${ }^{3}$ International Institute for Applied Systems Analysis (IIASA), Schlossplatz 1, 2361 Laxenburg, Austria.

\section{Acknowledgements}

This contribution is based on the "Early career researcher distinguished lecture" delivered by the first author at the 6th Asia Oceania Geosciences Society (AOGS) meeting in Beijing in August 2016. We thank the hydrological sciences section executive committee for the invitation to submit this paper. This study was partly supported by a research grant from the Asian Studies Center at Michigan State University. It was also partially supported by JICA/JST (SATREPS) and MEXT (SI-CAT).

\section{Competing interests}

The authors declare that they have no competing interests.

\section{Funding}

This study was partly supported by a research grant from the Asian Studies Center at Michigan State University, East Lansing, USA.

\section{Publisher's Note}

Springer Nature remains neutral with regard to jurisdictional claims in published maps and institutional affiliations.

Received: 13 December 2016 Accepted: 25 April 2017

Published online: 04 May 2017

\section{References}

AghaKouchak A, Norouzi H, Madani K, Mirchi A, Azarderakhsh M, Nazemi A, Nasrollahi N, Farahmand A, Mehran A, Hasanzadeh E (2015) Aral Sea syndrome desiccates Lake Urmia: call for action. J Great Lakes Res 41(1):307-311. doi:10.1016/j.jglr.2014.12.007

Arnell NW (1999) Climate change and global water resources. Glob Environ Chang 9:S31-S49. doi:10.1016/S0959-3780(99)00017-5

Beven KJ, Kirkby MJ (1979) A physically based, variable contributing area model of basin hydrology/Un modèle à base physique de zone d'appel variable de l'hydrologie du bassin versant. Hydrol Sci Bull 24(1):43-69. doi:10.1080/02626667909491834

Boucher O, Myhre G, Myhre A (2004) Direct human influence of irrigation on atmospheric water vapour and climate. Clim Dyn 22(6-7):597-603. doi:10.1007/s00382-004-0402-4

Carpenter SR, Stanley EH, Vander Zanden MJ (2011) State of the world's freshwater ecosystems: physical, chemical, and biological changes. Annu Rev Environ Resour 36(1):75-99. doi:10.1146/annurev-environ-021810-094524

Collatz GJ, Ball JT, Grivet C, Berry JA (1991) Physiological and environmental regulation of stomatal conductance, photosynthesis and transpiration: a model that includes a laminar boundary layer. Agric For Meteorol 54(2):107-136. doi:10.1016/0168-1923(91)90002-8

Crutzen PJ (2002) Geology of mankind. Nature 415(6867):23. doi:10.1038/415023a

Döll P (2009) Vulnerability to the impact of climate change on renewable groundwater resources: a global-scale assessment. Environ Res Lett 4(3):035006. doi:10.1088/1748-9326/4/3/035006

Döll P, Fiedler K, Zhang J (2009) Global-scale analysis of river flow alterations due to water withdrawals and reservoirs. Hydrol Earth Syst Sci 13(12):2413-2432. doi:10.5194/hess-13-2413-2009 
Döll P, Müller Schmied H, Schuh C, Portmann FT, Eicker A (2014) Global-scale assessment of groundwater depletion and related groundwater abstractions: combining hydrological modeling with information from well observations and GRACE satellites. Water Resour Res 50(7):5698-5720. doi :10.1002/2014WR015595

Dynesius M, Nilsson C (1994) Fragmentation and flow regulation of river systems in the northern third of the world. Science 266(5186):753-762. doi:10.1126/science. 266.5186 .753

Famiglietti JS (2014) The global groundwater crisis. Nat Clim Chang 4(11):945948. doi:10.1038/nclimate2425

Foley JA, DeFries R, Asner GP, Barford C, Bonan G, Carpenter SR, Chapin FS, Coe MT, Daily GC, Gibbs HK, Helkowski JH, Holloway T, Howard EA, Kucharik CJ, Monfreda C, Patz JA, Prentice IC, Ramankutty N, Snyder PK (2005) Global consequences of land use. Science 309(5734):570-574. doi:10.1126/science.1111772

Gleick PH (2003) Global freshwater resources: soft-path solutions for the 21st century. Science 302(5650):1524-1528. doi:10.1126/science.1089967

Gosling SN, Arnell NW (2016) A global assessment of the impact of climate change on water scarcity. Clim Chang 134(3):371-385. doi:10.1007/ s10584-013-0853-x

Haddeland I, Lettenmaier DP, Skaugen T (2006) Effects of irrigation on the water and energy balances of the Colorado and Mekong river basins. J Hydrol 324(1-4):210-223. doi:10.1016/j.jhydrol.2005.09.028

Haddeland I, Clark DB, Franssen W, Ludwig F, Voß F, Arnell NW, Bertrand N, Best M, Folwell S, Gerten D, Gomes S, Gosling SN, Hagemann S, Hanasaki N, Harding R, Heinke J, Kabat P, Koirala S, Oki T, Polcher J, Stacke T, Viterbo P, Weedon GP, Yeh P (2011) Multimodel estimate of the global terrestrial water balance: setup and first results. J Hydrometeorol 12(5):869-884. doi :10.1175/2011JHM1324.1

Haddeland I, Heinke J, Biemans H, Eisner S, Flörke M, Hanasaki N, Konzmann M, Ludwig F, Masaki Y, Schewe J, Stacke T, Tessler ZD, Wada Y, Wisser D (2014) Global water resources affected by human interventions and climate change. PNAS 111(9):3251-3256. doi:10.1073/pnas.1222475110

Hanasaki N, Fujimori S, Yamamoto T, Yoshikawa S, Masaki Y, Hijioka Y, Kainuma M, Kanamori Y, Masui T, Takahashi K, Kanae S (2013) A global water scarcity assessment under shared socio-economic pathways_-part 2: water availability and scarcity. Hydrol Earth Syst Sci 17(7):2393-2413. doi:10.5194/hess-17-2393-2013

Hasumi H, Emori S (2004) K-1 coupled model (MIROC) description. Center for climate system research. University of Tokyo, Tokyo

Joodaki G, Wahr J, Swenson S (2014) Estimating the human contribution to groundwater depletion in the Middle East, from GRACE data, land surface models, and well observations. Water Resour Res 50(3):2679-2692. doi:10.1002/2013WR014633

Kim H, Yeh PJF, Oki T, Kanae S (2009) Role of rivers in the seasonal variations of terrestrial water storage over global basins. Geophys Res Lett 36(17):L17402. doi:10.1029/2009GL039006

Koirala S, Yeh PJF, Hirabayashi Y, Kanae S, Oki T (2014) Global-scale land surface hydrologic modeling with the representation of water table dynamics. J Geophys Res Atmos 119(1):75-89. doi:10.1002/2013JD020398

Konikow LF (2013) groundwater depletion in the United States (1900-2008). US Geological Survey Scientific Investigations Report 2013-5079

Kueppers LM, Snyder MA, Sloan LC (2007) Irrigation cooling effect: regional climate forcing by land-use change. Geophys Res Lett 34(3):L03703. doi:1 0.1029/2006GL028679

Lawrence DM, Oleson KW, Flanner MG, Thornton PE, Swenson SC, Lawrence PJ, Zeng X, Yang Z-L, Levis S, Sakaguchi K, Bonan GB, Slater AG (2011) Parameterization improvements and functional and structural advances in Version 4 of the community land model. J Adv Model Earth Syst 3(1):M03001. doi:10.1029/2011MS00045

Lemoalle J (2004) Lake chad: a changing environment. In: Nihoul JCJ, Zavialov PO, Micklin PP (eds) Dying and dead seas climatic versus anthropic causes. NATO science series: IV: earth and environmental sciences, vol 36. Springer, Berlin, pp 321-339

Lewis SL, Maslin MA (2015) Defining the anthropocene. Nature 519(7542):171180. doi:10.1038/nature14258

Lo M-H, Famiglietti JS (2013) Irrigation in California's Central Valley strengthens the southwestern US water cycle. Geophys Res Lett 40(2):301-306. doi:10.1002/grl.50108

Long D, Scanlon BR, Lonquevergne L, Sun AY, Fernando DN, Save H (2013) GRACE satellite monitoring of large depletion in water storage in response to the 2011 drought in Texas. Geophys Res Lett 40(13):33953401. doi:10.1002/grl.50655

Marsh GP, Lowenthal D (1965) Man and nature. University of Washington Press, Washington

Micklin PP (1988) Desiccation of the Aral sea: a water management disaster in the Soviet Union. Science 241(4870):1170-1176. doi:10.1126/ science. 241.4870 .1170

Micklin P (2007) The Aral sea disaster. Annu Rev Earth Planet Sci 35(1):47-72. doi:10.1146/annurev.earth.35.031306.140120

Micklin P (2010) The past, present, and future Aral Sea. Lakes Reserv Res Manag 15(3):193-213. doi:10.1111/j.1440-1770.2010.00437.x

Micklin P (2014) Irrigation in the Aral Sea Basin. In: Micklin P, Aladin NV, Plotnikov I (eds) The Aral Sea. Springer, Berlin, pp 207-232

Milly PCD, Betancourt J, Falkenmark M, Hirsch RM, Kundzewicz ZW, Lettenmaier DP, Stouffer RJ (2008) Stationarity is dead: whither water management? Science 319(5863):573-574. doi:10.1126/science.1151915

Nazemi A, Wheater HS (2015a) On inclusion of water resource management in Earth system models — part 1: problem definition and representation of water demand. Hydrol Earth Syst Sci 19(1):33-61. doi:10.5194/ hess-19-33-2015

Nazemi A, Wheater HS (2015b) On inclusion of water resource management in Earth system models_-part 2: representation of water supply and allocation and opportunities for improved modeling. Hydrol Earth Syst Sci 19(1):63-90. doi:10.5194/hess-19-63-2015

Newbold T, Hudson LN, Arnell AP, Contu S, Palma AD, Ferrier S, Hill SLL, Hoskins AJ, Lysenko I, Phillips HRP, Burton VJ, Chng CWT, Emerson S, Gao D, Pask-Hale G, Hutton J, Jung M, Sanchez-Ortiz K, Simmons BI, Whitmee S, Zhang H, Scharlemann JPW, Purvis A (2016) Has land use pushed terrestrial biodiversity beyond the planetary boundary? A global assessment. Science 353(6296):288-291. doi:10.1126/science.aaf2201

Ngo-Duc T, Polcher J, Laval K (2005) A 53-year forcing data set for land surface models. J Geophys Res Atmos 110(D6):D06116. doi:10.1029/200 4JD005434

Nilsson C, Reidy CA, Dynesius M, Revenga C (2005) Fragmentation and flow regulation of the world's large river systems. Science 308(5720):405-408. doi:10.1126/science.1107887

Oki T, Kanae S (2006) Global hydrological cycles and world water resources. Science 313(5790):1068-1072. doi:10.1126/science.1128845

Oki T, Sud YC (1998) Design of total runoff integrating pathways (TRIP)—a global river channel network. Earth Interact 2(1):1-37. doi:10.1175/1087-3562(1998)002<0001:DOTRIP>2.3.CO;2

Pielke RA (2005) Land use and climate change. Science 310(5754):1625-1626. doi:10.1126/science.1120529

Pokhrel Y, Hanasaki N, Koirala S, Cho J, Yeh PJ-F, Kim H, Kanae S, Oki T (2012a) Incorporating anthropogenic water regulation modules into a land surface model. J Hydrometeorol 13(1):255-269. doi:10.1175/JHM-D-11-013.1

Pokhrel YN, Hanasaki N, Yeh PJ-F, Yamada TJ, Kanae S, Oki T (2012b) Model estimates of sea-level change due to anthropogenic impacts on terrestrial water storage. Nat Geosci 5(6):389-392. doi:10.1038/NGEO1476

Pokhrel YN, Fan Y, Miguez-Macho G (2014) Potential hydrologic changes in the Amazon by the end of the 21st century and the groundwater buffer. Environ Res Lett 9(8):084004. doi:10.1088/1748-9326/9/8/084004

Pokhrel YN, Koirala S, Yeh PJ-F, Hanasaki N, Longuevergne L, Kanae S, Oki T (2015) Incorporation of groundwater pumping in a global land surface model with the representation of human impacts. Water Resour Res 51(1):78-96. doi:10.1002/2014WR015602

Pokhrel YN, Hanasaki N, Wada Y, Kim H (2016) Recent progresses in incorporating human land-water management into global land surface models toward their integration into Earth system models. WIREs Water 3(4):548-574. doi:10.1002/wat2.1150

Postel S (1999) Pillar of sand: can the irrigation miracle last?. WW Norton \& Company, New York

Postel SL, Daily GC, Ehrlich PR (1996) Human appropriation of renewable fresh water. Science 271(5250):785-788. doi:10.1126/science.271.5250.785

Puma MJ, Cook BI (2010) Effects of irrigation on global climate during the 20th century. J Geophys Res Atmos 115(D16):D16120. doi:10.1029/201 0JD014122

Ramankutty N, Evan AT, Monfreda C, Foley JA (2008) Farming the planet: 1. Geographic distribution of global agricultural lands in the year 2000. Global Biogeochem Cycles 22(1):GB1003. doi:10.1029/2007GB002952 
Raskin P, Hansen E, Zhu Z, Stavisky D (1992) Simulation of water supply and demand in the Aral Sea Region. Water Int 17(2):55-67. doi:10.1080/02508069208686127

Richards LA (1931) Capillary conduction of liquids through porous mediums. J Appl Phys 1(5):318-333. doi:10.1063/1.1745010

Rockström J, Steffen W, Noone K, Persson Å, Chapin FS, Lambin EF, Lenton TM, Scheffer M, Folke C, Schellnhuber HJ, Nykvist B, de Wit CA, Hughes T, van der Leeuw S, Rodhe H, Sörlin S, Snyder PK, Costanza R, Svedin U, Falkenmark M, Karlberg L, Corell RW, Fabry VJ, Hansen J, Walker B, Liverman D, Richardson K, Crutzen P, Foley JA (2009) A safe operating space for humanity. Nature 461(7263):472-475. doi:10.1038/461472a

Rodell M, Velicogna I, Famiglietti JS (2009) Satellite-based estimates of groundwater depletion in India. Nature 460(7258):999-1002. doi:10.1038/ nature08238

Sacks WJ, Cook BI, Buenning N, Levis S, Helkowski JH (2009) Effects of global irrigation on the near-surface climate. Clim Dyn 33(2-3):159-175. doi:10.1007/s00382-008-0445-z

Sanderson EW, Jaiteh M, Levy MA, Redford KH, Wannebo AV, Woolmer G (2002) The Human footprint and the last of the wild. Bioscience 52(10):891-904. doi:10.1641/0006-3568(2002)052[0891:THFATL]2.0.CO;2

Scanlon BR, Faunt CC, Longuevergne L, Reedy RC, Alley WM, McGuire VL, McMahon PB (2012) Groundwater depletion and sustainability of irrigation in the US High Plains and Central Valley. PNAS 109(24):9320-9325. doi:10.1073/pnas.1200311109

Schewe J, Heinke J, Gerten D, Haddeland I, Arnell NW, Clark DB, Dankers R, Eisner S, Fekete BM, Colón-González FJ, Gosling SN, Kim H, Liu X, Masaki Y, Portmann FT, Satoh Y, Stacke T, Tang Q, Wada Y, Wisser D, Albrecht T, Frieler K, Piontek F, Warszawski L, Kabat P (2014) Multimodel assessment of water scarcity under climate change. PNAS 111(9):3245-3250. doi:10.1073/pnas.1222460110

Sellers PJ, Dickinson RE, Randall DA, Betts AK, Hall FG, Berry JA, Collatz GJ, Denning AS, Mooney HA, Nobre CA, Sato N, Field CB, HendersonSellers A (1997) Modeling the exchanges of energy, water, and carbon between Continents and the atmosphere. Science 275(5299):502-509. doi:10.1126/science.275.5299.502

Shibuo Y, Jarsjö J, Destouni G (2007) Hydrological responses to climate change and irrigation in the Aral Sea drainage basin. Geophys Res Lett 34(21):L21406. doi:10.1029/2007GL031465

Siebert S, Kummu M, Porkka M, Döll P, Ramankutty N, Scanlon BR (2015) A global data set of the extent of irrigated land from 1900 to 2005. Hydrol Earth Syst Sci 19(3):1521-1545. doi:10.5194/hess-19-1521-2015

Small EE, Sloan LC, Hostetler S, Giorgi F (1999) Simulating the water balance of the Aral Sea with a coupled regional climate-lake model. J Geophys Res Atmos 104(D6):6583-6602. doi:10.1029/98JD02348

Small EE, Giorgi F, Sloan LC, Hostetler S (2001) The effects of desiccation and climatic change on the hydrology of the Aral sea. J Clim 14(3):300-322. doi:10.1175/1520-0442(2001)013<0300:TEODAC>2.0.CO;2

Sorooshian S, Li J, K-I Hsu, Gao X (2011) How significant is the impact of irrigation on the local hydroclimate in California's Central Valley? Comparison of model results with ground and remote-sensing data. J Geophys Res Atmos 116(D6):D06102. doi:10.1029/2010JD014775
Sorooshian S, Li J, K-I Hsu, Gao X (2012) Influence of irrigation schemes used in regional climate models on evapotranspiration estimation: results and comparative studies from California's Central Valley agricultural regions. J Geophys Res Atmos 117(D6):D06107. doi:10.1029/2011JD016978

Steffen W, Crutzen PJ, McNeill JR (2007) The anthropocene: are humans now overwhelming the great forces of nature. AMBIO J Human Environ 36(8):614-621. doi:1 0.1579/0044-7447(2007)36[614:TAAHNO]2.0.CO;2

Stieglitz M, Rind D, Famiglietti J, Rosenzweig C (1997) An efficient approach to modeling the topographic control of surface hydrology for regional and global climate modeling. J Clim 10(1):118-137. doi:10.1175/1520-0442(1997)010<0118:AEATMT>2.0.CO;2

Takata K, Emori S, Watanabe T (2003) Development of the minimal advanced treatments of surface interaction and runoff. Glob Planet Chang 38(1-2):209-222. doi:10.1016/S0921-8181(03)00030-4

Tapley BD, Bettadpur S, Ries JC, Thompson PF, Watkins MM (2004) GRACE measurements of mass variability in the earth system. Science 305(5683):503-505. doi:10.1126/science.1099192

Vitousek PM, Mooney HA, Lubchenco J, Melillo JM (1997) Human domination of Earth's ecosystems. Science 277(5325):494-499. doi:10.1126/ science. 277.5325 .494

Vörösmarty CJ, Sharma KP, Fekete BM, Copeland AH, Holden J, Marble J, Lough JA (1997) The storage and aging of continental runoff in large reservoir systems of the world. Ambio 26(4):210-219

Vörösmarty CJ, McIntyre PB, Gessner MO, Dudgeon D, Prusevich A, Green P, Glidden S, Bunn SE, Sullivan CA, Liermann CR, Davies PM (2010) Global threats to human water security and river biodiversity. Nature 467(7315):555-561. doi:10.1038/nature09440

Voss KA, Famiglietti JS, Lo M, de Linage C, Rodell M, Swenson SC (2013) Groundwater depletion in the Middle East from GRACE with implications for transboundary water management in the Tigris-Euphrates-Western Iran region. Water Resour Res 49(2):904-914. doi:10.1002/wrcr.20078

Wada Y, van Beek LPH, van Kempen CM, Reckman JWTM, Vasak S, Bierkens MFP (2010) Global depletion of groundwater resources. Geophys Res Lett 37(20):L20402. doi:10.1029/2010GL044571

Wada Y, Wisser D, Eisner S, Flörke M, Gerten D, Haddeland I, Hanasaki N, Masaki Y, Portmann FT, Stacke T, Tessler Z (2013) Multimodel projections and uncertainties of irrigation water demand under climate change. Geophys Res Lett 40(17):4626-4632

Wagener T, Sivapalan M, Troch PA, McGlynn BL, Harman CJ, Gupta HV, Kumar P, Rao PSC, Basu NB, Wilson JS (2010) The future of hydrology: an evolving science for a changing world. Water Resour Res 46(5):W05301. doi:10.102 9/2009WR008906

Watanabe T (1994) Bulk parameterization for a vegetated surface and its application to a simulation of nocturnal drainage flow. Bound Layer Meteorol 70(1-2):13-35. doi:10.1007/BF00712521

Yeh PJF, Eltahir EAB (2005) Representation of water table dynamics in a land surface scheme part I: model development. J Clim 18(12):1861-1880. doi:10.1175/JCLI3330.1

\section{Submit your manuscript to a SpringerOpen ${ }^{\circ}$ journal and benefit from:}

- Convenient online submission

- Rigorous peer review

- Immediate publication on acceptance

- Open access: articles freely available online

- High visibility within the field

- Retaining the copyright to your article

Submit your next manuscript at $\boldsymbol{\nabla}$ springeropen.com 